\title{
46. MAGNETIC PROPERTIES OF BASALT SAMPLES FROM HOLES 504B AND 505B ON THE COSTA RICA RIFT, DEEP SEA DRILLING PROJECT LEGS 69 AND $70^{1}$
}

\author{
Toshio Furuta, Ocean Research Institute, University of Tokyo, Tokyo, Japan
}

\begin{abstract}
More than 60 basalt samples from two Deep Sea Drilling Project holes on the Costa Rica Rift were studied for magnetic properties and were found to have no properties significantly different from other DSDP basalts. Opaque mineralogical and thermomagnetic properties of these samples, however, to some extent show differences from normal submarine basalts; a new type of thermomagnetic curve and wide range of chemical compositions were recognized. Oxidized samples possibly containing incipient ilmenite exsolution lamellae were reduced and re-equilibrated during heating. The Curie temperatures of the re-equilibrated titanomagnetites are interpreted to be those of the original crystallized phase before oxidation.
\end{abstract}

\section{INTRODUCTION}

This work presents the results of magnetic and opaque-mineral studies of basaltic rocks recovered from Holes 504B and 505B during DSDP Leg 69 and Leg 70 in the Costa Rica Rift area (Fig. 1). Site 504 is located in an area of uniformly high heat flow. Site 505, on the other hand, is located in an area where heat flow is highly variable, but on the average much less than that predicted by theory (Langseth et al., this volume). The ages of Sites 504 and 505 are estimated to be 5.9 m.y. and 3.9 m.y., respectively, based on the magneticanomaly chart constructed during the pre-drilling survey (Langseth et al., this volume). The contrasts between the two sites raise some interesting questions: (1) How different are the magnetic properties of basement rocks between the high-heat-flow and low-heat-flow areas? (2) How much are the magnetic properties of basalts in the holes affected by hydrothermal alteration? In Hole 504B, the effects of hydrothermal alteration on the basalts were evident in the form of secondary minerals observed during shipboard petrographic study.

Magnetic and opaque-mineral studies of Hole 504B basalts indicate that they represent relatively young oceanic crust in the eastern Pacific. Detailed opaque-mineral examination indicates that the Costa Rica Rift basalts have unique properties in mineralogy and rock magnetism.

\section{EXPERIMENTAL PROCEDURES}

The samples used for laboratory magnetic measurements were the same as those used for paleomagnetic measurement on board Glomar Challenger during Leg 69. However, the samples recovered during Leg 70 are not the same as those treated by the shipboard party. Saturation magnetization and coercive force were measured by a vibration magnetometer with a strong field of $15 \mathrm{kOe}$, which is sufficient to saturate these oceanic basalts. Thermal changes in saturation magnetization were measured with a horizontal beam magnetic balance, on which a small chunk of rock $(\sim 100 \mathrm{mg})$ was heated at $6^{\circ} \mathrm{C} / \mathrm{min}$ in a magnetic field of $4.5 \mathrm{kOe}$. The samples were cooled to room temperature at the

\footnotetext{
${ }^{1}$ Cann, J. R., Langseth, M. G., Honnorez, J., Von Herzen, R. P., White, S. M., et al., Init. Repts. DSDP, 69: Washington (U.S. Govt. Printing Office).
}

same rate at which they were heated. The cycle of heating and cooling was accomplished in a vacuum of $10^{-5}$ to $10^{-6}$ torr. Some samples were measured in air to examine the differences between thermal behavior under different oxygen pressures. The opaque minerals in the basalts were examined in polished thin-sections using a reflectedlight microscope, and the chemical compositions of the minerals were determined with two electron-probe microanalyzers, JXA-5 (JEOL) and EMX-SM (Shimadzu Co. Ltd.).

\section{EXPERIMENTAL RESULTS}

The results of the magnetic measurements for individual samples are listed in Tables 1 and 2 in order of increasing depth in each hole. In this section, we present the data in terms of the vertical distribution of the magnetic properties in the holes.

\section{Saturation Magnetization, $J_{\mathrm{s}}$}

The observed whole-rock saturation magnetization, $J_{s}$, ranges from $0.236 \mathrm{emu} / \mathrm{g}$ to $0.954 \mathrm{emu} / \mathrm{g}$. These values are not significantly different from those of the other DSDP basalts (Ade-Hall et al., 1976; Day et al., 1978; Hamano et al., 1979) and show very limited variation. The saturation magnetization represents, to a first approximation, the amount of ferromagnetic minerals in the samples, so that variation in $J_{\mathrm{s}}$ could indicate variation in content of ferromagnetic minerals in each sample. The initial susceptibility, $x$, also represents the content of ferromagnetic minerals induced by weak field, so the relation between $J_{\mathrm{s}}$ and $x$ is theoretically a simple proportion. The relationship between them for the Hole 504B basalts is shown in Figure 2, but there is no good correlation between them.

\section{Saturation Remanent Magnetization, $J_{\mathrm{sr}}$}

The observed whole-rock remanence of saturation magnetization, $J_{\mathrm{sr}}$, ranges from 0.072 to $0.256 \mathrm{emu} / \mathrm{g}$. In general, saturation remanent magnetization depends upon the magnetic-mineral content and grain size. The ratio $J_{s r} / J_{s}$ is a simple function of the grain size, independent of magnetic concentration. The $J_{\mathrm{sr}} / J_{\mathrm{s}}$ ratio ranges from 0.135 to 0.468 ; such a small variation is due to the small range of grain sizes in the Hole 504B 


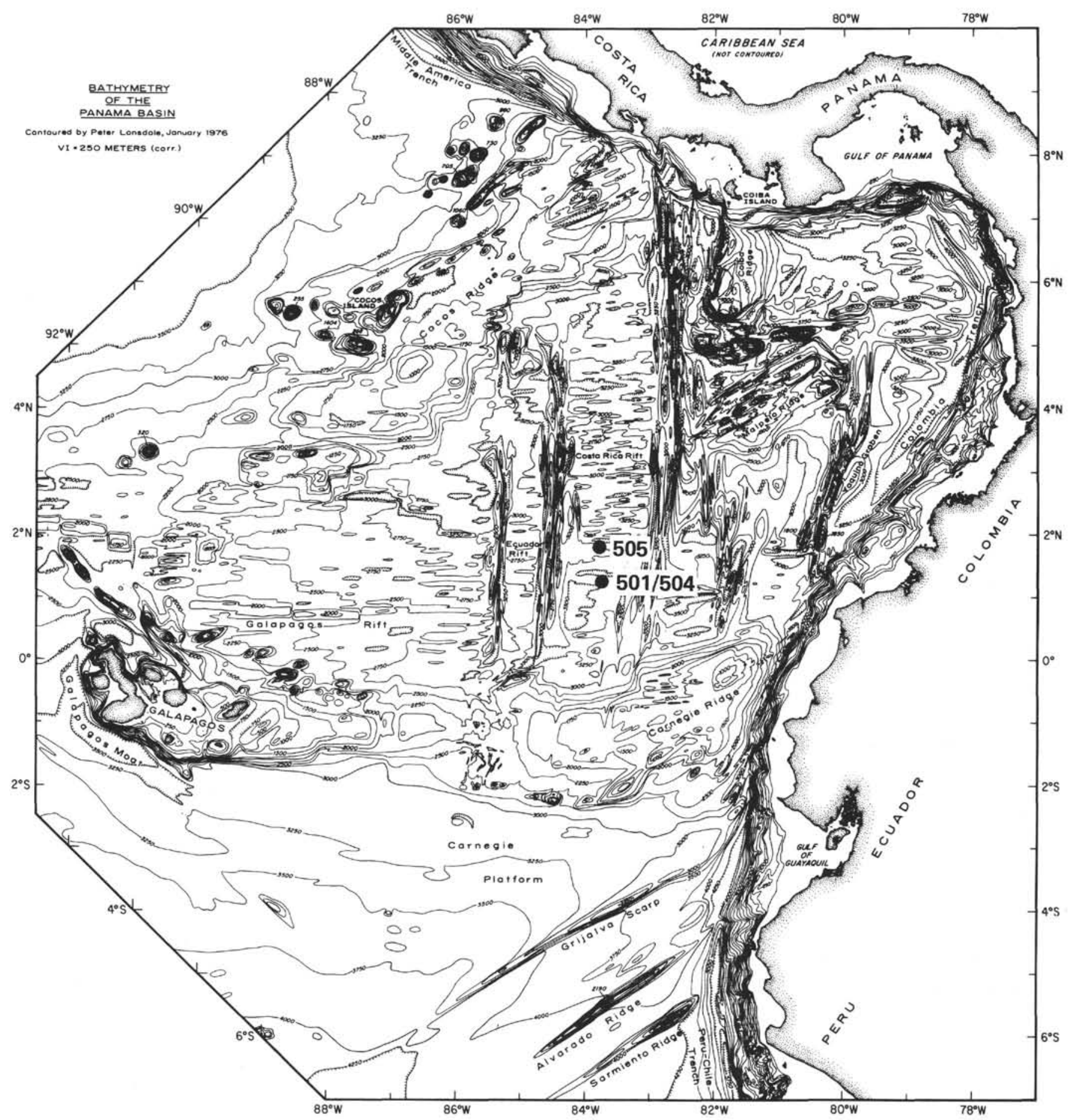

Figure 1. Location of Sites 504 and 505, near the Costa Rica Rift.

basalts. $J_{\mathrm{sr}}$ and $J_{\mathrm{n}}$ are roughly proportional; as $J_{\mathrm{sr}}$ increases, $J_{\mathrm{n}}$ also increases (Fig. 3).

\section{Coercive Force, $H_{\mathrm{c}}$, and Remanent}

Coercive Force, $\boldsymbol{H}_{\mathrm{rc}}$

Coercive force, $H_{\mathrm{c}}$, and remanent coercive force, $H_{\mathrm{rc}}$, range from 34 to $450 \mathrm{Oe}$ and from 75 to $550 \mathrm{Oe}$, respectively, showing a wide range of bulk coercivity. $H_{\mathrm{c}}$ and MDF show a good, normal correlation for these samples (Fig. 4). Day et al. (1977) demonstrated that a value of $H_{\mathrm{rc}} / H_{\mathrm{c}}$ less than 4.0 is obtained from samples whose titanomagnetites are pseudo-single-domain or single-domain crystals. The titanomagnetites in all samples from Hole 504B should be of pseudo-single or single domain, as their $H_{\mathrm{rc}} / H_{\mathrm{c}}$ values are all less than 4.0.

\section{Thermomagnetic Measurement}

Thermal changes in saturation magnetization were measured on 79 samples from Hole 504B, and 8 samples from Hole 505B. The results are listed in Table 2. The 
Table 1. Magnetic properties of Hole 504B basalts.

\begin{tabular}{|c|c|c|c|c|c|c|c|c|c|c|}
\hline $\begin{array}{c}\text { Sample } \\
\text { (interval in } \mathrm{cm} \text { ) }\end{array}$ & $\left(10^{-3}-\frac{J_{7}}{G}\right)$ & $\left(10^{-4}-4\right)$ & $\begin{array}{l}\mathrm{MDF} \\
(\mathrm{Oe})\end{array}$ & $\begin{array}{c}J_{s} \\
(\mathrm{emu} / \mathrm{g})\end{array}$ & $\underset{(\mathrm{emu} / \mathrm{g})}{J_{S \mathrm{r}}}$ & $J_{\mathrm{sr}} / J_{\mathrm{s}}$ & $\begin{array}{l}H_{\mathrm{c}} \\
(\mathrm{Oe})\end{array}$ & $\begin{array}{l}H_{\mathrm{rc}} \\
(\mathrm{Oe})\end{array}$ & $H_{\mathrm{rc}} / H_{\mathrm{c}}$ & $\begin{array}{l}\text { Rock } \\
\text { Type }\end{array}$ \\
\hline 504B-3-1, 87-89 & 4.2 & 17.5 & 120 & 0.598 & 0.154 & 0.258 & 65.2 & 105 & 1.6 & M \\
\hline $3-1,108-110$ & 7.1 & 14.9 & 110 & 0.586 & 0.135 & 0.230 & 64.6 & 154 & 2.4 & M \\
\hline $4-1,108-110$ & 9.5 & 5.8 & 260 & 0.236 & 0.108 & 0.458 & 190 & 275 & 1.4 & P \\
\hline $4-2,101-103$ & 21.0 & 7.8 & 240 & 0.496 & 0.198 & 0.399 & 158 & 215 & 1.4 & $\mathbf{P}$ \\
\hline $4-3,122-124$ & 15.1 & 5.6 & 400 & 0.402 & 0.173 & 0.430 & 450 & 395 & 0.9 & $\mathbf{P}$ \\
\hline $4-5,124-126$ & 10.7 & 9.7 & 230 & 0.464 & 0.178 & 0.384 & 131 & 210 & 1.6 & P \\
\hline $5-1,57-59$ & 12.8 & 9.6 & 170 & 0.466 & 0.178 & 0.382 & 100 & 171 & 1.7 & P \\
\hline $5-2,41-43$ & 17.6 & 7.6 & 180 & 0.518 & 0.208 & 0.402 & 122 & 187 & 1.5 & P \\
\hline $6-1,55-57$ & 9.2 & 4.0 & 430 & 0.348 & 0.163 & 0.468 & 155 & 287 & 1.9 & P \\
\hline $6-2,35-38$ & 5.1 & 15.0 & 145 & 0.614 & 0.241 & 0.376 & 86 & 138 & 1.6 & M \\
\hline $7-1,33-35$ & 11.7 & 3.1 & 550 & 0.580 & 0.156 & 0.269 & 350 & 550 & 1.6 & P \\
\hline $7-3,127-129$ & 12.0 & 11.4 & 120 & 0.658 & 0.206 & 0.313 & 77 & 120 & 1.6 & M \\
\hline $7-4,35-37$ & 8.9 & 13.2 & 130 & 0.648 & 0.179 & 0.276 & 77 & 140 & 1.8 & M \\
\hline $7-5,3-5$ & 8.6 & 15.7 & 100 & 0.762 & 0.142 & 0.186 & 76 & 136 & 1.8 & M \\
\hline $8-1,59-61$ & 1.6 & 14.8 & 75 & 0.498 & 0.079 & 0.158 & 58 & 106 & 1.8 & M \\
\hline $8-2,86-88$ & 6.2 & 16.0 & 110 & 0.708 & 0.099 & 0.140 & 43 & 90 & 2.1 & M \\
\hline $8-3,73-75$ & 4.2 & 15.6 & 115 & 0.687 & 0.120 & 0.175 & 54 & 95 & 1.8 & M \\
\hline $8-4,58-60$ & 5.4 & 13.6 & 110 & 0.698 & 0.175 & 0.225 & 72 & 128 & 1.8 & M \\
\hline $9-1,51-53$ & 28.8 & 8.2 & 200 & 0.547 & 0.256 & 0.468 & 142 & 190 & 1.3 & $\mathbf{P}$ \\
\hline $9-2,73-75$ & 3.1 & 15.3 & 130 & 0.490 & 0.109 & 0.222 & 64 & 112 & 1.8 & M \\
\hline $10-2,11-13$ & 3.0 & 14.7 & 140 & 0.492 & 0.130 & 0.264 & 63 & 122 & 1.9 & M \\
\hline $11-1,19-21$ & 0.5 & 10.3 & 180 & 0.350 & 0.085 & 0.243 & 81 & 165 & 2.0 & M \\
\hline $11-3,27-29$ & 0.8 & 9.8 & 170 & 0.276 & 0.072 & 0.261 & 86 & 152 & 1.8 & M \\
\hline $12-2,107-109$ & 1.0 & 13.6 & 170 & 0.444 & 0.098 & 0.221 & 76 & 148 & 1.9 & M \\
\hline $13-1,140-142$ & 0.8 & 12.0 & 180 & 0.368 & 0.076 & 0.207 & 72 & 130 & 1.8 & M \\
\hline $13-3,71-73$ & 4.5 & 17.6 & 140 & 0.648 & 0.165 & 0.255 & 80 & 140 & 1.8 & M \\
\hline $13-4,15-17$ & 4.4 & 15.8 & 80 & 0.564 & 0.100 & 0.177 & 49 & 80 & 1.6 & M \\
\hline $14-1,39-41$ & 7.0 & 15.2 & 160 & 0.676 & 0.178 & 0.263 & 109 & 204 & 1.9 & $\mathbf{P}$ \\
\hline $15-2,26-28$ & 1.2 & 12.8 & 160 & 0.416 & 0.089 & 0.214 & 52 & 140 & 2.8 & M \\
\hline $15-3,138-140$ & 1.7 & 17.2 & 150 & 0.356 & 0.072 & 0.202 & 72 & 156 & 2.2 & M \\
\hline $15-4,129-131$ & 5.7 & 13.4 & 180 & 0.560 & 0.169 & 0.302 & 118 & 195 & 1.7 & $\mathbf{P}$ \\
\hline $15-5,52-54$ & 2.6 & 16.5 & 125 & 0.494 & 0.104 & 0.211 & 66 & 120 & 1.8 & M \\
\hline $16-1,20-22$ & 2.2 & 15.8 & 130 & 0.680 & 0.159 & 0.234 & 82 & 140 & 1.7 & M \\
\hline $16-2,6-8$ & 0.8 & 15.7 & 180 & 0.640 & 0.120 & 0.188 & 59 & 110 & 1.9 & M \\
\hline $16-3,134-136$ & 6.5 & 13.9 & 150 & 0.526 & 0.175 & 0.333 & 100 & 150 & 1.5 & P \\
\hline $17-1,96-98$ & 4.7 & 14.8 & 160 & 0.506 & 0.135 & 0.367 & 98 & 170 & 1.7 & $\mathbf{P}$ \\
\hline $18-1,71-73$ & 13.8 & 14.2 & 110 & 0.570 & 0.143 & 0.251 & 87 & 155 & 1.8 & P? \\
\hline $19-1,101-103$ & 7.0 & 6.0 & 210 & 0.398 & 0.184 & 0.462 & 149 & 215 & 1.4 & P \\
\hline $19-2,86-88$ & 2.8 & 15.6 & 125 & 0.628 & 0.152 & 0.242 & 84 & 150 & 1.8 & M \\
\hline $20-1,109-111$ & 2.5 & 15.5 & 105 & 0.762 & 0.116 & 0.152 & 48 & 93 & 1.9 & M \\
\hline $21-1,137-140$ & 2.1 & 17.4 & 145 & 0.782 & 0.120 & 0.153 & 52 & 110 & 2.1 & M \\
\hline $21-4,136-138$ & 3.7 & 16.9 & 170 & 0.576 & 0.143 & 0.248 & 105 & 198 & 1.9 & M \\
\hline $22-1,62-64$ & 4.3 & 6.9 & 370 & 0.322 & 0.144 & 0.447 & 232 & 400 & 1.7 & P \\
\hline $23-1,88-90$ & 4.9 & 16.5 & 160 & 0.626 & 0.146 & 0.232 & 104 & 172 & 1.7 & M \\
\hline $24-1,100-102$ & 6.5 & 11.5 & 160 & 0.302 & 0.103 & 0.341 & 136 & 230 & 1.7 & P \\
\hline $24-3,76-78$ & 5.8 & 13.1 & 180 & 0.512 & 0.149 & 0.291 & 126 & 210 & 1.7 & $\mathbf{P}$ \\
\hline $25-2,83-85$ & 0.7 & 24.5 & 110 & 0.640 & 0.095 & 0.148 & 58 & 130 & 2.2 & M \\
\hline $27-1,109-111$ & 0.9 & 23.6 & 85 & 0.716 & 0.097 & 0.135 & 47 & 105 & 2.2 & M \\
\hline $27-2,106-108$ & 4.5 & 9.5 & 200 & 0.436 & 0.155 & 0.356 & 126 & 205 & 1.6 & $\mathrm{P}$ \\
\hline $28-1,95-97$ & 3.3 & 22.8 & 60 & 0.954 & 0.171 & 0.179 & 34 & 75 & 2.2 & M \\
\hline $28-3,56-58$ & 4.4 & 17.1 & 160 & 0.556 & 0.162 & 0.291 & 110 & 190 & 1.7 & P \\
\hline $28-4,123-125$ & 0.4 & 27.5 & 200 & 0.824 & 0.138 & 0.167 & 54 & 115 & 2.1 & M \\
\hline $29-1,4-6$ & 6.2 & 12.6 & 140 & 0.432 & 0.129 & 0.299 & 88 & 156 & 1.8 & M \\
\hline
\end{tabular}

listed parameters are $T_{\mathrm{cl}}$, the first Curie temperature observed during heating: $T_{\mathrm{c} 2}$, the highest Curie temperature during heating; $T_{\mathrm{ch}}$, the secondary Curie temperature during cooling; and $J_{\mathrm{h}} / J_{0}$, the ratio of the saturation magnetization observed at room temperature and after and before heating.

There are four types of thermomagnetic curves; a thermally reversible type (Fig. 5A; type I), and three irreversible types (Fig. 5B-D, types II-IV). Type I shows a reversible curve, and its Curie temperature may represent original or slightly oxidized titanomagnetite of the samples. Type II commonly is observed among submarine basalts (Fig. 5B). Titanomagnetite of type II is oxidized at low temperatures, and its curve has a typical dent which has been explained as the inversion point of titanomaghemite (Ozima and Ozima, 1971). Type III is similar to Type II; it has a similar hysteresis, but cooling results in very different behavior. The final $J_{s}$, denoted by $J_{\mathrm{h}}$ in Table 2 , does not increase by more than onehalf of the initial $J_{s}$, denoted by $J_{0}$ in Table 2 (Fig. 5C). This hysteresis is not common in submarine basalts. Type IV behaves as a single phase during heating, with the Curie temperature around $400^{\circ} \mathrm{C}$, and without the dent commonly observed in samples oxidized at low temperature (Fig. 5D). During cooling, $J_{\mathrm{s}}$ slowly increases with $T_{\text {ch }}$ of around $200^{\circ} \mathrm{C}$.

For reversible type I, the Curie temperature is easily determined, as shown in Figure 5A. The Curie temperature of this type slightly decreases after heating in some cases. In the upper part of Hole 504B, type I behavior was found in only two of 62 samples. Although there are few samples from Hole 505B, half of all samples were recognized as type I. Most of the other samples were irreversible, as commonly found for basalts oxidized at low temperatures.

Among the irreversible samples of type II, cooling results in a steep increase in $J_{s}$, as seen in typical oceanic basalts (Fig. 5B) and in some terrestrial volcanic rocks (Furuta et al., 1980). Although type III samples show curves similar to those of type II samples during heating, their cooling curves show a very slow increase in $J_{s}$, with a convex curve, compared with the heating curve (Fig. 5C). Moreover, a new type of thermal curve is recognized: $J_{\mathrm{s}}$ gradually decreases as temperature increases up to $300^{\circ} \mathrm{C}$, but $J_{s}$ stays nearly the same while temperature continuously increases from 300 to $500^{\circ} \mathrm{C}$. After the temperature exceeds $500^{\circ} \mathrm{C} . J_{\mathrm{s}}$ decreases again (Fig. 6 ). These samples seem to have variable composition of 
Table 2. Thermomagnetic and opaque-mineral properties of basalts from Holes 504B and 505B.

\begin{tabular}{|c|c|c|c|c|c|c|c|c|}
\hline $\begin{array}{c}\text { Sample } \\
\text { (interval in } \mathrm{cm} \text { ) }\end{array}$ & $T_{\mathrm{c} 1}$ & $T_{\mathrm{c} 2}$ & $T_{\mathrm{ch}}$ & $J_{\mathrm{h}} / J_{0}$ & Type & $x$ Values & $\begin{array}{c}\text { Grain } \\
\text { Size }\end{array}$ & $\begin{array}{c}\mathrm{Ti} / \mathrm{Fe} \\
\text { Mol Ratio } \\
\text { of Ilmenite }\end{array}$ \\
\hline B-3-1, 87-89 & 305 & 470 & 185 & 0.7 & III & - & 17 & - \\
\hline $3-1,108-110$ & 300 & 545 & 485 & 1.6 & III & $0.543 \pm 0.0$ & 14 & - \\
\hline $4-1,108-110$ & 310 & 470 & 340 & 1.0 & III & - & & - \\
\hline $4-2,101-103$ & 255 & & 200 & 0.8 & I & - & 15 & - \\
\hline $4-3,122-124$ & 310 & 480 & 275 & 1.1 & III & - & 12 & - \\
\hline $4-5,124-126$ & 300 & 520 & 490 & 1.8 & II & - & & - \\
\hline $5-1,57-59$ & 295 & 520 & 500 & 1.6 & II & - & 17 & - \\
\hline $5-2,41-43$ & 300 & 465 & 270 & 0.9 & III & -- & & $\overline{0}$ \\
\hline $6-1,55-57$ & 230 & 495 & 235 & 1.2 & III & $0.535 \pm 0.022$ & 30 & 0.787 \\
\hline $6-2,35$ & 295 & 555 & 525 & 1.7 & II & $0.430 \pm 0.021$ & 28 & - \\
\hline $7-1,33-35$ & 310 & 460 & 430 & 1.5 & II & - & 3 & - \\
\hline $7-2,98$ & 310 & 465 & 230 & 0.9 & III & - & - & - \\
\hline $7-3,12$ & 285 & 500 & 215 & 0.8 & III & - & $\bar{\pi}$ & - \\
\hline $7-4,35-37$ & 300 & 530 & 500 & 1.5 & II & - & 17 & - \\
\hline $7-5,3-5$ & 300 & 495 & 430 & 1.1 & II & $\left\{\begin{array}{l}0.641 \pm 0.022 \\
0.430 \pm 0.016\end{array}\right\}$ & 34 & 0.757 \\
\hline $8-1,59-61$ & 300 & 525 & 500 & 1.8 & II & $0.672 \pm 0.010$ & 113 & - \\
\hline $8=86-88$ & 300 & 460 & 285 & 0.9 & III & $0.643 \pm 0.004$ & 120 & - \\
\hline $8-3,73-75$ & 305 & 505 & 500 & 1.3 & II & - & $=0$ & - \\
\hline $8-4,58-60$ & 355 & 580 & 535 & 1.7 & II & $0.641 \pm 0.021$ & 100 & - \\
\hline $9-1,51-53$ & 250 & - & 190 & 0.9 & I & - & 7 & - \\
\hline $9-2,73-75$ & 325 & 515 & 455 & 1.3 & iI & - & - & - \\
\hline $10-2,11-13$ & 330 & 515 & 455 & 1.3 & iI & - & 7 & - \\
\hline $11-1,19-21$ & 335 & 505 & 340 & 1.0 & III & 0.564 & 15 & - \\
\hline $11-2,76-78$ & 305 & 530 & 510 & 1.9 & II & - & 12 & - \\
\hline $11-3,27-29$ & 345 & 505 & 305 & 10 & III & - & 7 & - \\
\hline & 315 & 510 & 510 & 1.7 & II & - & 10 & - \\
\hline $12-2,107-109$ & 325 & 490 & 275 & 0.9 & III & - & - & - \\
\hline $13-1,140-142$ & 325 & 465 & 180 & 0.6 & III & - & $z$ & - \\
\hline $\begin{array}{l}13-2,100-102 \\
13-3,7-73\end{array}$ & 305 & 540 & 485 & 1.6 & II & $\bar{z}$ & $=$ & $\bar{z}$ \\
\hline $\begin{array}{l}13-3,71-73 \\
13-4,15-17\end{array}$ & $\begin{array}{l}310 \\
310\end{array}$ & 490 & 280 & $\begin{array}{l}0.9 \\
0.8\end{array}$ & $\begin{array}{l}\text { III } \\
\text { III }\end{array}$ & $0630=0.068$ & $\overline{17}$ & $=$ \\
\hline $\begin{array}{l}14-4,15-17 \\
14-1,39-41\end{array}$ & $\begin{array}{l}310 \\
310\end{array}$ & $\begin{array}{l}480 \\
490\end{array}$ & $\begin{array}{l}2000 \\
340\end{array}$ & $\begin{array}{l}0.8 \\
1.0\end{array}$ & III & $0.630 \pm 0.068$ & $\begin{array}{r}17 \\
4\end{array}$ & $=$ \\
\hline $15-2,26-28$ & 330 & 480 & 195 & 0.8 & III & $=$ & $\begin{array}{l}4 \\
5\end{array}$ & $\bar{z}$ \\
\hline $15-3,138-140$ & 340 & 490 & 240 & 0.9 & III & $=$ & 8 & $=$ \\
\hline $15-4,129-131$ & 345 & 470 & 355 & 1.0 & III & - & - & $=$ \\
\hline $15-5,52-54$ & 335 & 500 & 455 & 0.9 & III & $0.698 \pm 0.014$ & 60 & $\overline{-}$ \\
\hline $16-1,20-22$ & 320 & 530 & 475 & 1.5 & II & - & 16 & $\overline{-}$ \\
\hline $16-2,6-8$ & 315 & 480 & 480 & 0.9 & III & - & 16 & $\bar{z}$ \\
\hline $16-3,66-68$ & 350 & 520 & 500 & 1.5 & II & - & - & $\bar{z}$ \\
\hline $16-3,134-136$ & 310 & 440 & 280 & 0.9 & III & - & - & $\bar{z}$ \\
\hline $16-4,105-107$ & 335 & 485 & 270 & 0.9 & III & - & - & $\bar{z}$ \\
\hline $17-1,96-9$ & 310 & 500 & 465 & 1.4 & II & - & - & $\bar{z}$ \\
\hline $17-2,104-106$ & 315 & 500 & 450 & 1.2 & 11 & - & 18 & $\bar{z}$ \\
\hline $18-1,71-7$ & 310 & 485 & 225 & 0.8 & III & - & 10 & $=$ \\
\hline $19-1$, & 305 & 480 & 410 & 1. & II & - & & - \\
\hline $19-2,86-88$ & & 510 & 485 & 1.4 & II & - & 7 & - \\
\hline $20-1,109-111$ & 315 & 505 & 530 & 1.3 & II & $684 \pm 0.010$ & 40 & - \\
\hline $21-1,137-140$ & 320 & 520 & 510 & $\begin{array}{l}1.5 \\
1.5\end{array}$ & II & $665 \pm 0.004$ & 52 & - \\
\hline $21-2,59-61$ & 450 & 470 & 220 & 0.6 & III & - & - & - \\
\hline $21-3,123-125$ & 310 & 530 & 505 & 1.6 & II & $0.719 \pm 0.009$ & 22 & - \\
\hline $21-4,136-138$ & 350 & 495 & 395 & 1.0 & III & - & 24 & - \\
\hline $22-1,62-64$ & 390 & 420 & 370 & 1.2 & III & - & 4 & - \\
\hline $23-1,88-90$ & 330 & 495 & 475 & 1.4 & II & - & 5 & - \\
\hline $24-1,100-102$ & 335 & 480 & 360 & 0.9 & III & - & 6 & - \\
\hline $24-3,76-78$ & 340 & 490 & 405 & 1.1 & III & - & 9 & - \\
\hline $25-2,83-85$ & 365 & 510 & 470 & 1.1 & II & - & 15 & - \\
\hline $27-1,105$ & 345 & 520 & 495 & 1.3 & II & $0.657 \pm 0.005$ & 33 & - \\
\hline $27-2,10$ & 350 & 485 & 190 & 07 & III & - & 4 & - \\
\hline 28-1, & 325 & 445 & 435 & 0.9 & III & $0.609 \pm 0.005$ & so & - \\
\hline & 340 & 475 & 335 & 0. & III & - & 8 & - \\
\hline $28-4,123-125$ & 360 & 525 & 505 & 10 & $\pi$ & - & - & - \\
\hline 29-1 & 350 & 510 & 530 & 1.5 & II & - & - & - \\
\hline $\begin{array}{l}33-2,72 \\
34-2,59\end{array}$ & 350 & 485 & 320 & 9 & III & - & $\bar{z}$ & $=$ \\
\hline $\begin{array}{l}36-2,59-61 \\
36-2,85-87\end{array}$ & $\begin{array}{l}525 \\
295\end{array}$ & $\bar{z}$ & $\begin{array}{l}440 \\
190\end{array}$ & 0.7 & ${ }_{1}^{10}$ & $616 \pm 0.050$ & $\overline{80}$ & $0 . \overline{944}$ \\
\hline 36 & 385 & - & 370 & 0.9 & I & - & - & - \\
\hline $38-1,84$ & 485 & - & 455 & 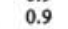 & IV & - & - & - \\
\hline $40-3,36$ & 250 & - & 185 & 8 & I & - & - & - \\
\hline $41-1,11$ & 260 & - & 190 & 0. & I & - & - & - \\
\hline $42-2$ & 420 & 475 & 480 & 1.0 & II & - & - & - \\
\hline 45. & 420 & - & 27 & 0. & IV & - & - & - \\
\hline & 420 & - & 21 & 0 & IV & - & - & - \\
\hline 52 & 32 & - & $3 c$ & 0. & 1 & $653 \pm 0$. & - & - \\
\hline 57 & 33 & - & & 0 & IV & $678 \pm 0.021$ & - & - \\
\hline $61-2,8$ & 41 & - & 2 & 0 & IV & - & - & - \\
\hline $62-1,10$ & 420 & - & 15 & 0. & IV & - & - & - \\
\hline $64-4,3$ & 455 & - & 455 & 0.6 & IV & $0.573 \pm 0.078$ & - & - \\
\hline $70-1,20-$ & 57 & - & 570 & 0 & 1 & - & - & - \\
\hline $\begin{array}{r}70-2,21-24 \\
\text { B- } 2-1,115-1\end{array}$ & 530 & $\bar{z}$ & 530 & & 1 & - & $\overline{10}$ & - \\
\hline $\begin{array}{c}\text { B-2-1, 115-117 } \\
2-2,81-83\end{array}$ & $\begin{array}{l}220 \\
300\end{array}$ & $\overline{510}$ & $\begin{array}{l}220 \\
425\end{array}$ & $\begin{array}{l}1.0 \\
1.4\end{array}$ & I & $\bar{z}$ & $\begin{array}{r}12 \\
7\end{array}$ & $\bar{z}$ \\
\hline $3-1,114-116$ & 225 & - & 190 & 1.0 & 1 & $=$ & 13 & $=$ \\
\hline $3-2,86-88$ & 320 & 560 & 585 & 2.3 & II & & 20 & - \\
\hline $4-1,10-12$ & 285 & 485 & 490 & 1.5 & III & $\left\{\begin{array}{l}0.606 \\
0.475\end{array}\right\}$ & 33 & 0.709 \\
\hline $5-1,3$ & 200 & - & 180 & 1.0 & 1 & & 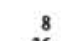 & - \\
\hline & 205 & - & 210 & 1.0 & 1 & $0.476 \pm 0.0$ & 36 & - \\
\hline $6-2,6-8$ & 310 & 535 & 530 & 2.7 & II & 0.532 & 16 & 0.887 \\
\hline
\end{tabular}

Notes: $T_{\mathrm{c} 1}=$ first Curie temperatures observed during heating: $T_{\mathrm{C} 2}=$ highest Curie temperatures observed during heating: $T_{\mathrm{ch}}=$ second Curie temperatures observed during cooling: $J_{\mathrm{h}} / J_{0}=$ peratures in a ${ }^{\circ} \mathrm{C}$. type magnetization observed at room temperature after and before heating, tem. peratures in ${ }^{\circ} \mathrm{C}$; type (thermomagnetic curves explained in text); grain size $=$ averages of largest represents one standard deviation; $\mathrm{Ti} / \mathrm{Fe}$ mol ratio of ilmenite $3 \mathrm{O}_{4}$ : uncertainty of $x$ value menite grains.

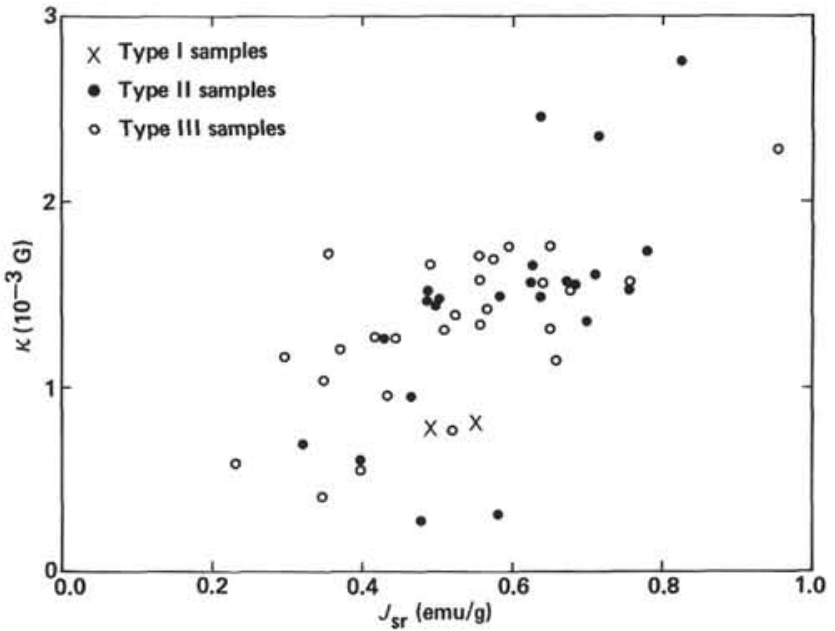

Figure 2. Relationship between initial susceptibility, $x$, and saturation magnetization, $J_{s}$, for basalts from Hole 504B.

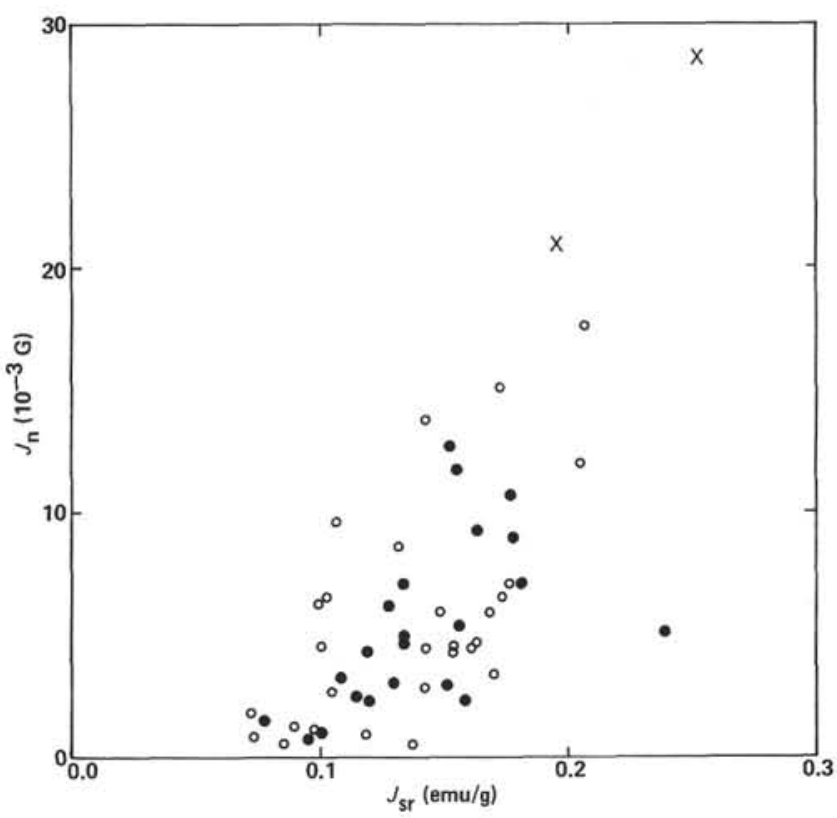

Figure 3. Relationship between intensity of NRM, $J_{\mathrm{n}}$, and saturation remanent magnetization, $J_{\mathrm{sr}}$, for basalts from Hole 504B. Symbols as in Figure 2.

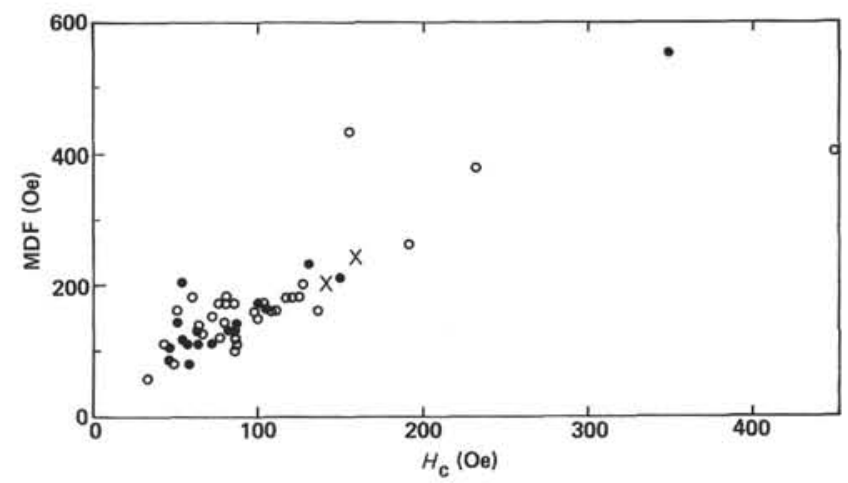

Figure 4. Correlation between median destructive field, MDF and coercive force, $H_{c}$, for basalts from Hole 504B. Symbols as in Figure 1. 

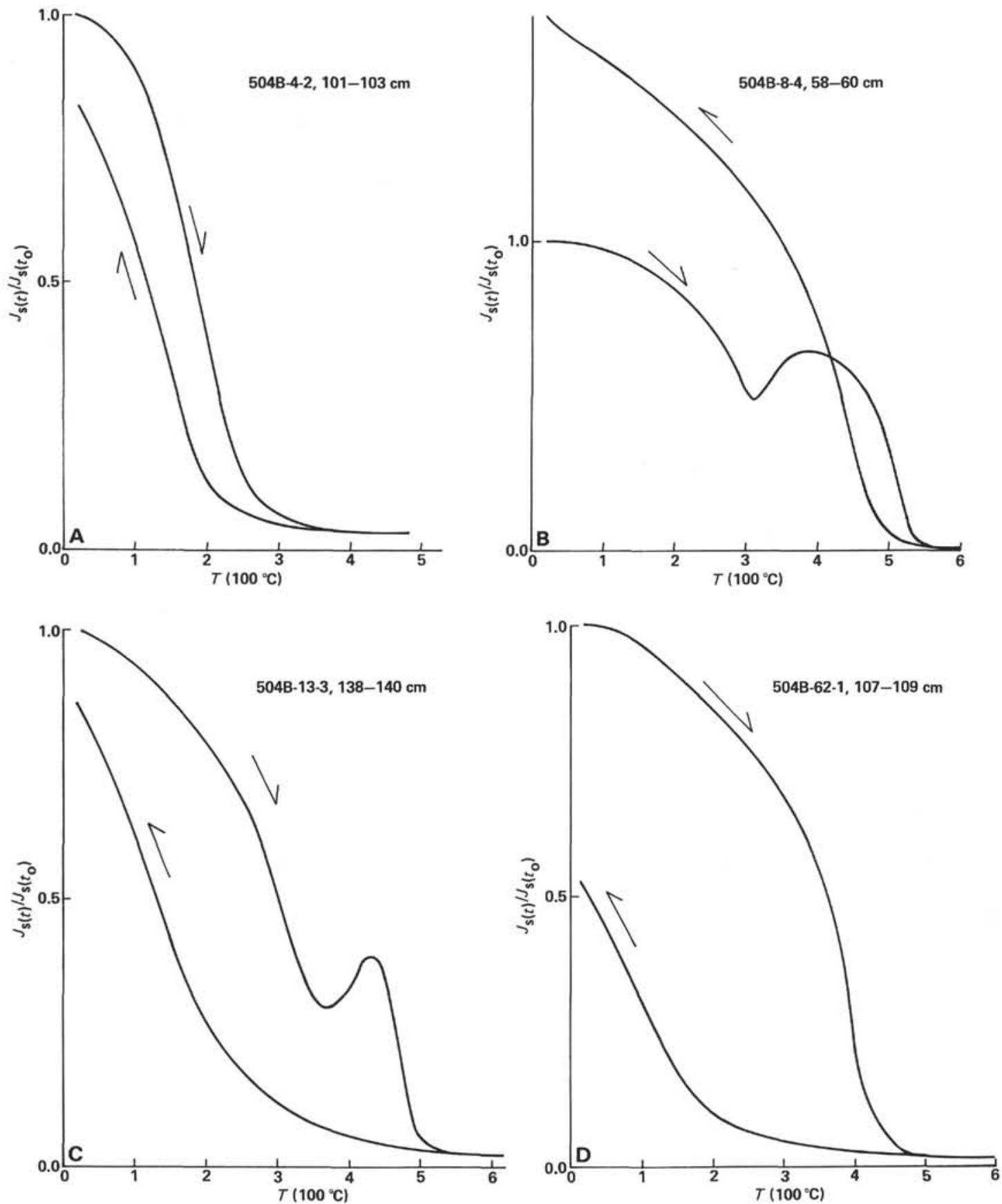

Figure 5. Principal types of thermomagnetic curves. A. Type I, nearly thermally reversible. B. Type II, typical irreversible curve observed for basalts oxidized at low temperature. C. Type III, thermally irreversible, with low $T_{\mathrm{ch}}$. D. Type IV, thermally irreversible with high $T_{\mathrm{c} 1}$ and low $T_{\mathrm{ch}}$.

titanomagnetites whose Curie temperatures range from 300 to $500^{\circ} \mathrm{C}$. The thermal curve for an air measurement of this sample is also shown in Figure 6. The curve has two bends, at temperatures of 300 and $500^{\circ} \mathrm{C}$, and the final $J_{\mathrm{s}}\left(J_{\mathrm{h}}\right)$ is similar to the initial $J_{\mathrm{s}}\left(J_{0}\right) . T_{\mathrm{ch}}$ in air is higher than in vacuum, and its value is the same as the Curie temperature of magnetite.

The ratios of $J_{\mathrm{h}} / J_{0}$ calculated from the thermal analysis curves are listed in Table 2 . These ratios for type I samples are around 1, for type II samples the ratios are larger than 1, and for type III and IV samples the ratios are near or less than 1 . Ratios greater than 2 , as found for example among typical samples oxidized at low temperature, were not observed in any samples from Hole 504B.

\section{Microscopic Observation of Opaque Minerals}

Opaque minerals were examined in polished thin-sections using a reflected-light microscope. Titanomagnetite is distinguished from ilmenite and iron sulfide by its color or anisotropy. Titanomagnetite oxidized at low temperature (titanomaghemite) can be distinguished 


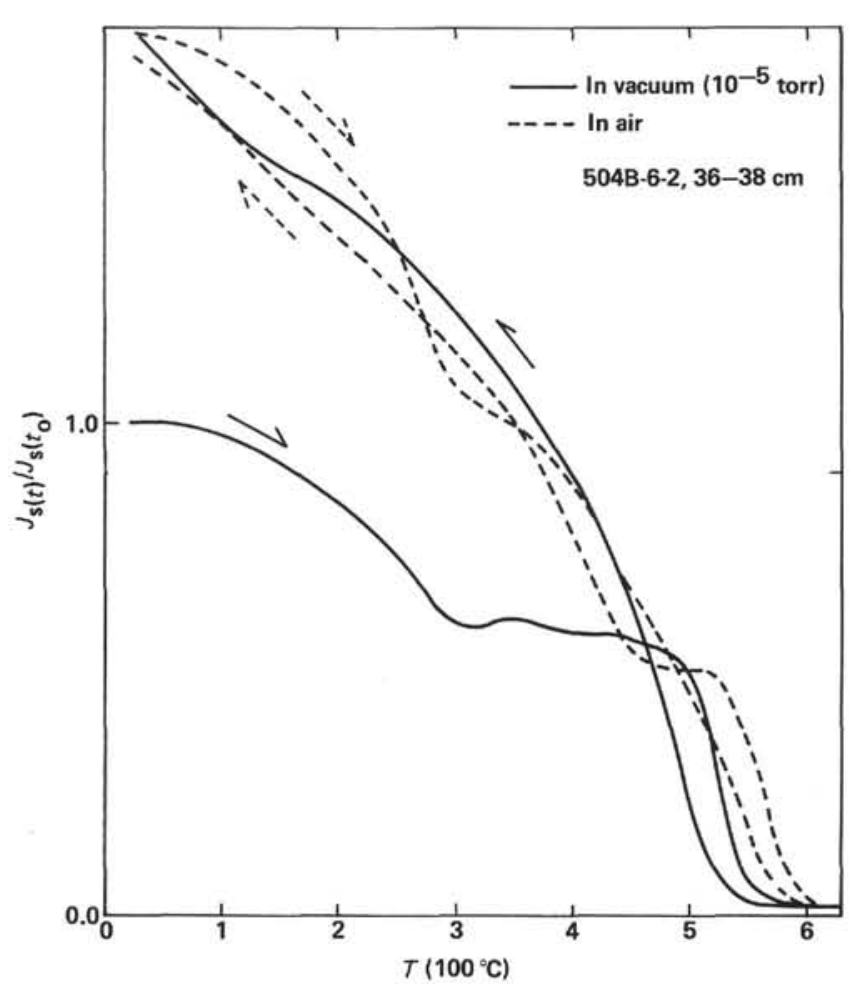

Figure 6. A new type of thermomagnetic curve. The intensity of saturation magnetization apparently stays the same during temperature increase from 300 to $500^{\circ} \mathrm{C}$.

from non-oxidized titanomagnetite by its color. However, because most grains of titanomagnetite in these samples are very small, we could not find obvious differences between titanomagnetite and titanomaghemite under the microscope.

There apparently are different grain sizes and crystal shapes in the same section of some samples, which can be classified into groups. One group consists of relatively large, skeletal or herring-bone-shaped crystals (Fig. 7), and the other consists of small, platey crystals. These samples show a new type of thermomagnetic curve, suggesting a mixture of wide compositional ranges derived from different crystallization stages of titanomagnetites (e.g., 504B-7-5, 3-5 cm). Data from microprobe analysis support these implications.

Visually estimated grain size listed in Table 2 is the average of the largest 10 grains observed in the sample microscopically. According to other magnetic measurements, such as $J_{s}, J_{\mathrm{sr}}, H_{\mathrm{c}}$, and $H_{\mathrm{rc}}$, these might not represent the true magnetic grain size, because titanomagnetites often are divided into several magnetic domains by the development of cracks resulting from oxidation (Johnson and Hall, 1978) and exsolution of fine ilmenite lamellae.

\section{Chemical Analysis of Opaque Minerals}

$\mathrm{The} \mathrm{Ti} / \mathrm{Fe}$ ratio in titanomagnetite and ilmenite was determined with two different electron-probe microanalyzers. Chemical compositions of titanomagnetite and ilmenite were measured on 19 samples from Hole 504B and five samples from Hole 505B. The compositions of more than 20 grains per specimen were determined, and the values were averaged (Table 3). The contents of other elements besides $\mathrm{Fe}$ and $\mathrm{Ti}$ were measured also in the same grains. The atomic ratio of $\mathrm{Ti} / \mathrm{Fe}$ was obtained, and the $x$ value of the ulvospinel-magnetite solid solution $\left[x \mathrm{Fe}_{2} \mathrm{TiO}_{4} \cdot(1-x) \mathrm{Fe}_{3} \mathrm{O}_{4}\right]$ or its oxidized product was calculated on the assumption of a stoichiometric ulvospinel-magnetite series. Detailed analysis of a few samples indicated that the contents of other elements are less than a few percent.

In general, it is well known that the $x$ value of submarine basalts has a small variation and is around the value of 0.6. Johnson and Hall (1978) demonstrated that the $x$ value of non-oxidized or oxidized titanomagnetites of submarine basalts from the Pacific Ocean and the Atlantic Ocean does not vary significantly from an average value of $0.62 \pm 0.05$. The $x$ value of titanomagnetites in some samples from Hole 504B is to some extent different from the normal value for submarine basalts. For example, Sample 504B-6-2, 36-38 cm contains titanomagnetites with a wide range of $x$ values, from 0.3

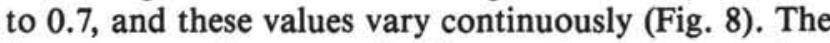
thermomagnetic curve of this sample also suggests a wide range of compositions of titanomagnetites.

Correlation between $\mathrm{Al}_{2} \mathrm{O}_{3}$ content (representative of minor components in titanomagnetite) and the $x$ value of titanomagnetites in this sample is good. As the $x$ value increases or titanium content increases, the $\mathrm{Al}_{2} \mathrm{O}_{3}$ content decreases, whereas as the $x$ value decreases, $\mathrm{MnO}$ and $\mathrm{MgO}$ contents increase. The titanomagnetites in Sample 504B-7-5, 3-5 cm are divided into four $x$ value groups; groups I and II have a low $x$ value, around 0.43 , but these two groups are subdivided clearly on the basis of different contents of $\mathrm{Al}_{2} \mathrm{O}_{3}$. Group III has a normal value of submarine basalts, around 0.64 . Group IV resembles pure magnetite. The results of chemical analysis of Sample 504B-7-5, 3-5 cm are listed in Table 3 and shown in Figure 9.

\section{DISCUSSION}

We discuss here two main problems concerning magnetic, thermomagnetic, and opaque-mineral properties.

\section{Paleomagnetic and Rock Magnetic Properties}

The results given in Table 1 and Figures 2 through 4 indicate that these basalts are not significantly different from other DSDP basalts. The averaged magnetic results of both pillow lavas and massive flows are listed in Table 4. Other magnetic properties, the intensity of natural remanent magnetization $\left(J_{\mathrm{n}}\right)$, and the initial susceptibility $(\kappa)$, based on shipboard data, are discussed in Furuta and Levi (this volume).

If the grain size of magnetic minerals is of a single domain, the intensity of NRM is proportional to the saturation magnetization. As shown in Figure 10, there is no correlation between $J_{\mathrm{n}}$ and $J_{s}$. This suggests that the grain size of these samples is larger than that of single domain. From examination of $J_{\mathrm{sr}} / J_{\mathrm{s}}$ versus $H_{\mathrm{rc}} / H_{\mathrm{c}}$ (Fig. 11), however, the grain size of these samples may be of single-domain or pseudo-single-domain structures. Therefore, the intensity of NRM might be reduced because of strong alteration, so that the correla- 

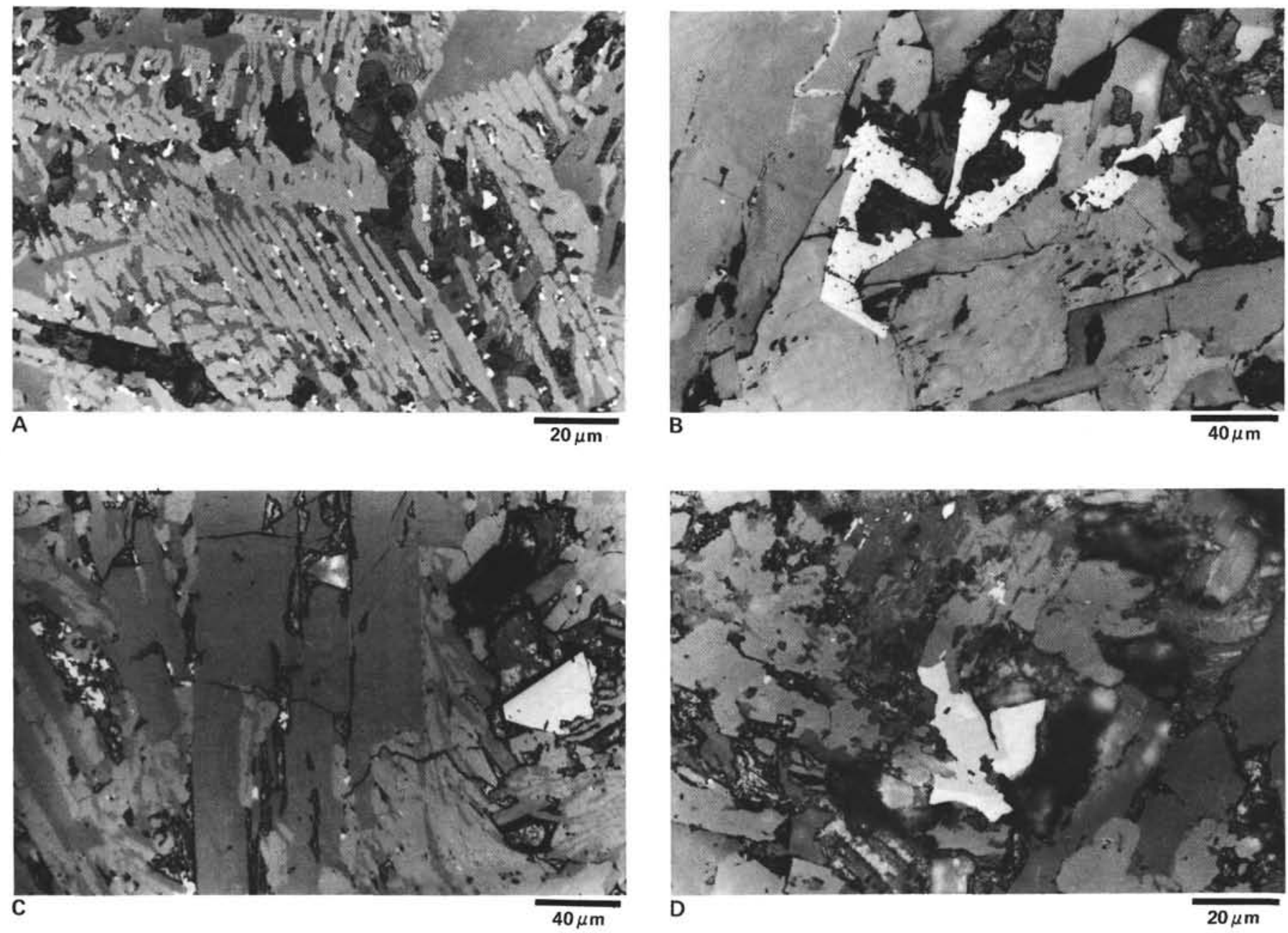

Figure 7. Photomicrographs of typical opaque minerals in reflected light. A. Typical titanomagnetite in pillow basalts. These grains were sufficiently oxidized at low temperature (504B-27-2, 106-108 cm). B. Typical titanomagnetites in massive flow basalts $(504 \mathrm{~B}-8-1,59-61 \mathrm{~cm})$. C. An example of different crystallization of titanomagnetites in the same sample, large grain (right) and small grains (left) (504B-6-2, 35-38 cm). D. Co-existence of hemo-ilmenite (light color) and apparent magnetite (dark color) (504B-7-5, 3-5 cm).

Table 3. Chemical composition of titanomagnetites (analyses 1-21) and discrete ilmenites (analyses 22-23) in Sample 504B-7-5, 3-5 cm.

\begin{tabular}{|c|c|c|c|c|c|c|c|c|c|c|c|c|c|c|c|}
\hline \multirow[b]{2}{*}{ Parameter } & \multicolumn{15}{|c|}{ Analysis } \\
\hline & 1 & 2 & 3 & 4 & 5 & 6 & $\begin{array}{c}\text { Mean of } \\
1-6 \text { (Group I) }\end{array}$ & 7 & 8 & 9 & 10 & $\begin{array}{c}\text { Mean of } \\
7-10 \text { (Group II) }\end{array}$ & 11 & 12 & 13 \\
\hline $\mathrm{Al}_{2} \mathrm{O}_{3}$ & 2.12 & 1.66 & 2.01 & 2.02 & 2.47 & 2.60 & 2.14 & 0.86 & 0.73 & 1.19 & 0.88 & 0.92 & 1.47 & 1.13 & 2.26 \\
\hline $\mathrm{TiO}_{2}$ & 14.16 & 13.70 & 15.73 & 14.64 & 10.96 & 14.67 & 13.88 & 16.32 & 13.33 & 11.64 & 14.62 & 13.98 & 21.40 & 20.05 & 22.21 \\
\hline $\mathrm{FeO}^{\circ}$ & 72.62 & 74.95 & 73.18 & 75.91 & 78.86 & 74.19 & 74.95 & 73.94 & 76.73 & 76.86 & 74.41 & 75.49 & 68.41 & 69.32 & 65.55 \\
\hline $\mathrm{Ti} / \mathrm{Fe}(\mathrm{mol} \mathrm{\%})$ & 0.175 & 0.164 & 0.193 & 0.173 & 0.125 & 0.178 & 0.168 & 0.198 & 0.156 & 0.136 & 0.177 & 0.167 & 0.281 & 0.260 & 0.305 \\
\hline$x$ values & 0.448 & 0.424 & 0.486 & 0.444 & 0.333 & 0.453 & 0.431 & 0.497 & 0.406 & 0.360 & 0.450 & 0.428 & 0.659 & 0.619 & 0.701 \\
\hline
\end{tabular}

\begin{tabular}{|c|c|c|c|c|c|c|c|c|c|c|c|c|c|}
\hline Parameter & 14 & 15 & 16 & 17 & $\begin{array}{c}\text { Mean of } \\
11-17 \text { (Group III) }\end{array}$ & 18 & 19 & 20 & $\begin{array}{c}\text { Mean of } \\
18-20 \text { (Group IV) }\end{array}$ & 21 & 22 & 23 & $\begin{array}{c}\text { Mean } \\
\text { of Ilmenites }\end{array}$ \\
\hline $\mathrm{Al}_{2} \mathrm{O}_{3}$ & 1.65 & 1.24 & 1.41 & 1.55 & 1.53 & 0.33 & 0.46 & 0.43 & 0.41 & 0.24 & 0.24 & 0.20 & 0.23 \\
\hline $\mathrm{TiO}_{2}$ & 21.70 & 19.74 & 19.32 & 21.50 & 20.85 & 0.32 & 0.88 & 0.37 & 0.52 & 42.55 & 40.11 & 44.48 & 42.38 \\
\hline $\mathrm{FeO}^{*}$ & 69.27 & 71.24 & 70.38 & 68.72 & 68.98 & 86.87 & 86.02 & 86.58 & 86.49 & 49.79 & 53.94 & 47.86 & 50.53 \\
\hline $\mathrm{Ti} / \mathrm{Fe}(\mathrm{mol} \mathrm{\%})$ & 0.282 & 0.249 & 0.247 & 0.281 & 0.272 & 0.003 & 0.009 & 0.004 & 0.005 & 0.768 & 0.669 & 0.836 & 0.758 \\
\hline$x$ values & 0.659 & 0.598 & 0.594 & 0.659 & 0.641 & 0.009 & 0.021 & 0.011 & 0.013 & & & & \\
\hline
\end{tabular}

tion between $J_{\mathrm{n}}$ and $J_{\mathrm{s}}$ is dispersed by the effects of weathering, mainly hydrothermal alteration and lowtemperature oxidation. The relationship between $J_{\mathrm{n}}$ and $J_{\mathrm{r}}$ is roughly proportional (Fig. 3 ). $J_{\mathrm{sr}}$ depends on grain size and shape, because the grain size decreases (i.e., $J_{\mathrm{r}}$ increases) as $J_{\mathrm{n}}$ increases. From the results of two rela- tions $-J_{\mathrm{n}}$ versus $J_{\mathrm{sr}}$ and $J_{\mathrm{n}}$ versus $J_{\mathrm{s}}-$ the intensity of NRM of the present samples appears to depend more upon the grain size than magnetic concentration.

The effects of magnetic-grain size on various magnetic properties were demonstrated by Day et al. (1978). According to their results, the ratio of $H_{\mathrm{rc}} / H_{\mathrm{c}}$ is one of 


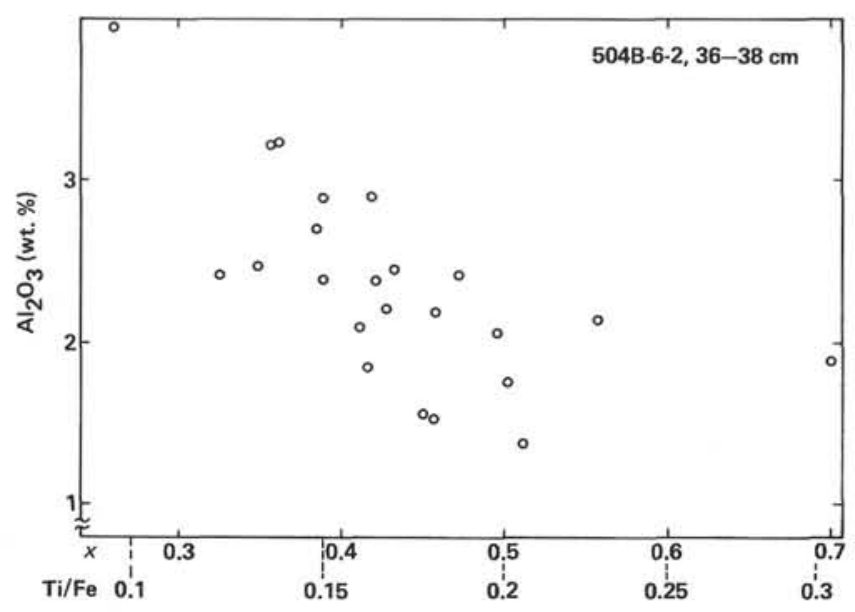

Figure 8. Variation of $x$ value (or $\mathrm{Ti} / \mathrm{Fe}$ ratio) with content of $\mathrm{Al}_{2} \mathrm{O}_{3}$ for titanomagnetites in Sample 504B-6-2, 36-38 cm.

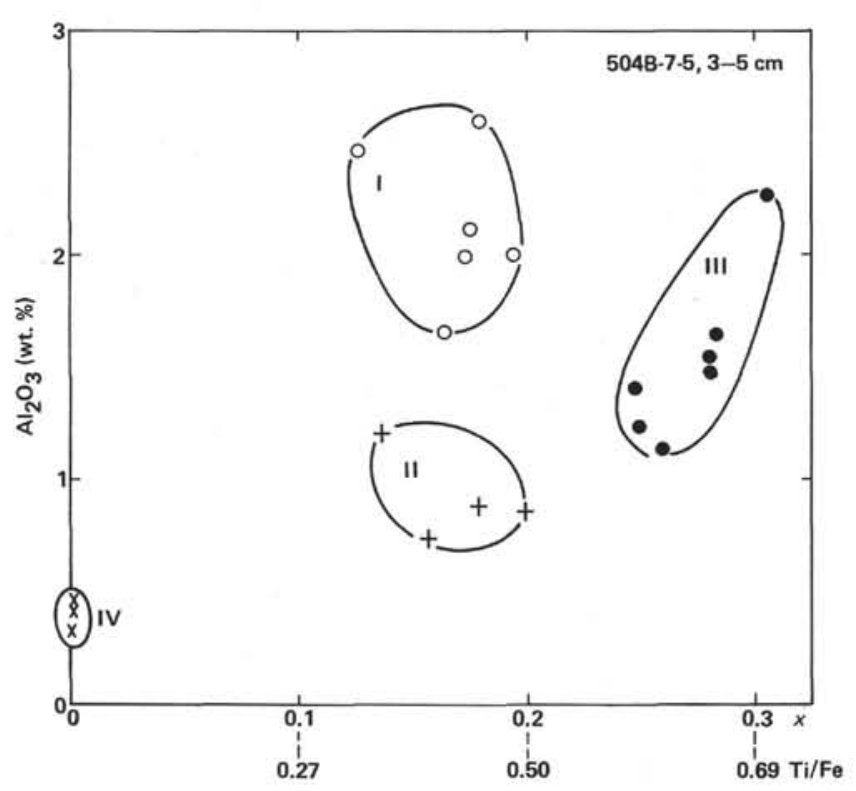

Figure 9. Variation of $x$ values (or $\mathrm{Ti} / \mathrm{Fe}$ ratio) with content of $\mathrm{Al}_{2} \mathrm{O}_{3}$ for titanomagnetites in Sample 504B-7-5, 3-5 cm. Data are divided into four groups on the basis of $x$ value and contents of $\mathrm{Al}_{2} \mathrm{O}_{3}$. Group number corresponds to that in Table 3.

the factors suitable for determination of magnetic-grain size. When the ratio of $H_{\mathrm{rc}} / H_{\mathrm{c}}$ is less than 1.5, the grains are single-domain. The grains whose value of this ratio is more than $\mathbf{4}$ are multi-domain, and their critical size is a value of about $30 \mu \mathrm{m}$ to $40 \mu \mathrm{m}$ for $x=0.6$ of titanomagnetite. The ratio of $H_{\mathrm{rc}} / H_{\mathrm{c}}$ of Hole 504B basalts is less than 4 , so that the magnetic minerals in these basalts seems to be of pseudo-single or single-domain size. Figure 11 shows the relationship between $J_{\mathrm{sr}} / J_{\mathrm{s}}$ and $H_{\mathrm{rc}} / H_{\mathrm{c}}$; the data reported by Day et al. (1978) are also plotted in this figure. The values seem to shift left parallel to synthetic-titanomagnetite values. The cause of this shift is not yet clear, but oxidation might be responsible for this behavior. No correlations between $J_{\mathrm{n}}$ and visual grain size determined with the microscope could be found (Fig. 12). There is only one weak correlation: $J_{\mathrm{n}}$ normalized by $J_{\mathrm{s}}$ decreases as visual grain size increases.

Finally, MDF and coercive force are important to determine, in order to define the paleomagnetic stability. Figure 4 shows the strong correlation between MDF and $H_{\mathrm{c}}$, indicating that the data from Hole 504B are sufficiently reliable to use for discussion of paleomagnetic problems.

\section{Thermomagnetic and Opaque-Mineral Properties}

There are four types of thermomagnetic hysteresis among the present samples, as discussed earlier. Thermomagnetic curves can be used to estimate the kinds of ferromagnetic minerals that are contained in the samples. From the thermal hysteresis curves, we can conveniently obtain important information, such as Curie temperature and oxidation state of individual samples.

The proportion of samples with thermally reversible curves (type I) is different in the two holes. Only two of 62 samples from the upper part of Hole 504B are type I samples, whereas four of 8 samples of Hole 505B are type I. This difference suggests that the basalts of the sites have experienced different conditions of oxidation. Site 504 and 505 are located respectively at high- and low-heat-flow areas. If the source of hydrothermal circulation stays fixed relative to basement rocks, which migrate with plate motion, basalts in high-heat-flow areas should always be subjected to alteration by hydrothermal circulation (Karato and Becker, in press). Most of the basalts from the upper part of Hole 504B were oxidized at low temperature; the cause of oxidation may be not only greater crustal age than those of Hole 505B, but also a higher activity of hydrothermal circulation. Basalts from the lower part of Hole 504B have not undergone low-temperature oxidation. This difference of oxidation in basalts of Hole 504B may indicate the different nature of alteration, that is, the alteration in the upper part of the hole was oxidative, whereas that of the lower part was non-oxidative (CRRUST, in press).

Some samples have curves similar to those of type II up to $300^{\circ} \mathrm{C}$, but beyond $300^{\circ} \mathrm{C} J_{s}$ remains constant until $500^{\circ} \mathrm{C}$ (Fig. 6). This new type of thermal curve previously has not been found in any submarine basalts. It suggests that the titanomagnetites in these samples have

Table 4. Averaged magnetic properties of Hole 504B basalts.

\begin{tabular}{|c|c|c|c|c|c|c|c|c|c|}
\hline Rock Type & $N$ & $\begin{array}{c}J_{\mathrm{n}} \\
\left(10^{-3} \mathrm{G}\right)\end{array}$ & $\left(10^{-4} \mathrm{G}\right)$ & $\underset{(\mathrm{emu} / \mathrm{g})}{J_{\mathrm{S}}}$ & $\begin{array}{c}J_{\mathrm{Sr}} \\
(\mathrm{emu} / \mathrm{g})\end{array}$ & $J_{\mathrm{sr}} / J_{\mathrm{S}}$ & $\begin{array}{l}H_{\mathrm{c}} \\
(\mathrm{Oe})\end{array}$ & $\begin{array}{l}H_{\mathrm{rc}} \\
(\mathrm{Oe})\end{array}$ & $H_{\mathrm{rc}} / H_{\mathrm{c}}$ \\
\hline Pillow lava & 20 & $10.3 \pm 6.4$ & $9.9 \pm 4.1$ & $0.47 \pm 0.11$ & $0.17 \pm 0.03$ & $0.37 \pm 0.07$ & $159 \pm 90$ & $240 \pm 100$ & $1.58 \pm 0.23$ \\
\hline Massive flow & 33 & $3.5 \pm 2.7$ & $15.9 \pm 3.8$ & $0.59 \pm 0.15$ & $0.13 \pm 0.04$ & $0.22 \pm 0.06$ & $68 \pm 17$ & $128 \pm 28$ & $1.93 \pm 0.25$ \\
\hline
\end{tabular}




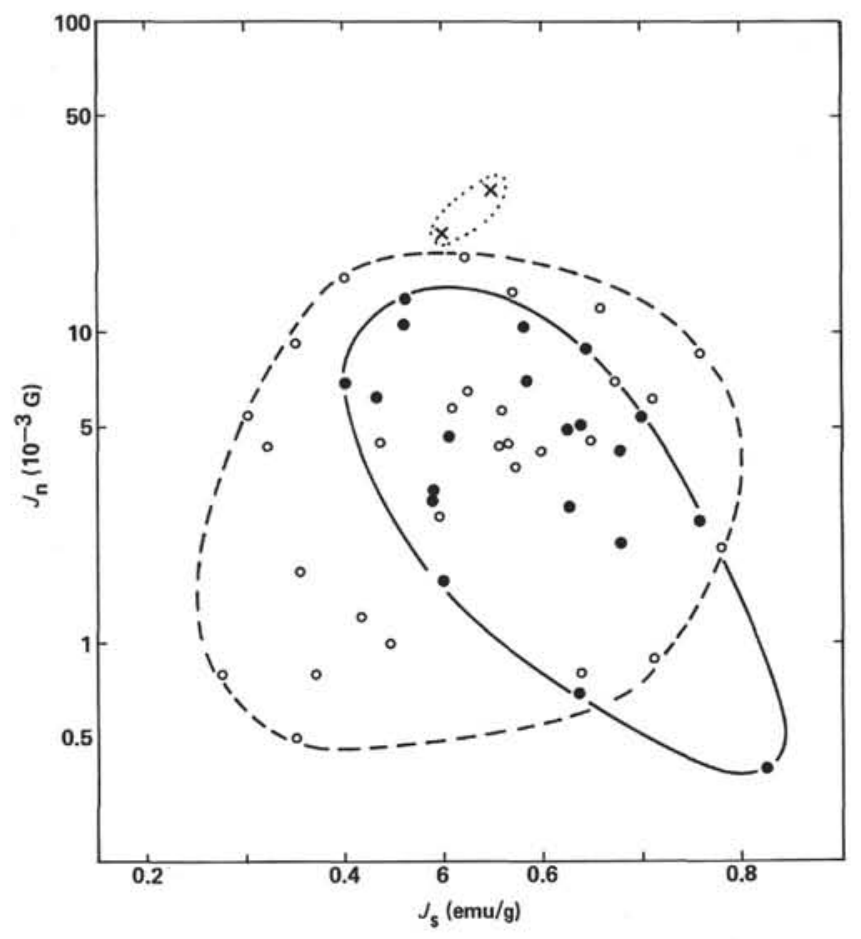

Figure 10. Relationship between intensity of NRM, $J_{\mathrm{n}}$, and saturation magnetization $J_{s}$, for basalts from Hole 504B. Symbols as in Figure 1.

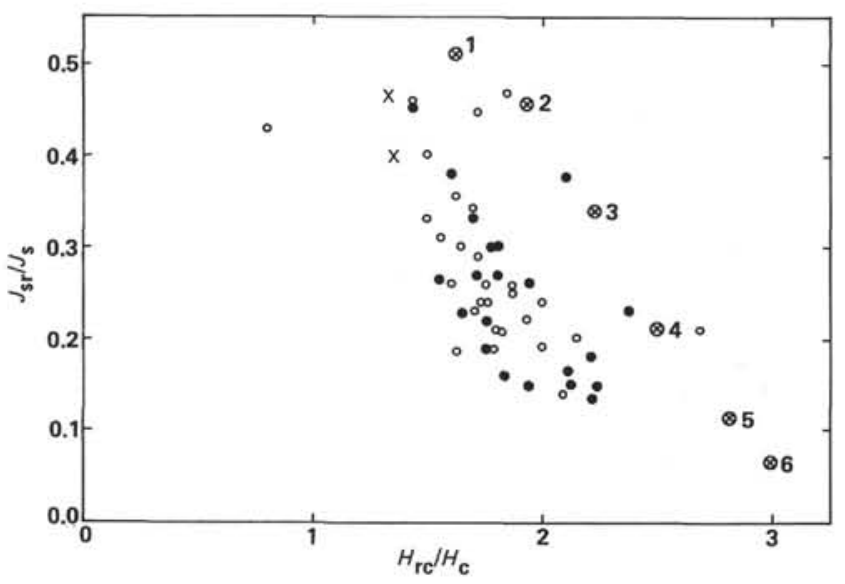

Figure 11. Relationship between $J_{\mathrm{sr}} / J_{\mathrm{s}}$ and $H_{\mathrm{rc}} / H_{\mathrm{c}}$ for basalts from Hole 504B. Circled crosses represent data from synthetic titanomagnetites $(\mathrm{x}=0.6)$ after Day et al. Other symbols as in Figure 1. 1: $0.94 \mu \mathrm{m}, 2: 1.7 \mu \mathrm{m}, 3: 3.3 \mu \mathrm{m}, 4: 6.4 \mu \mathrm{m}, 5: 12 \mu \mathrm{m}, 6: 25.5 \mu \mathrm{m}$.

a wide range of composition, and Curie temperatures ranging from 300 to $500^{\circ} \mathrm{C}$. The $x$ values of titanomagnetites having such high Curie temperatures are less than 0.6 . The $x$ values of submarine basalts from several different areas shows a small variation, being around 0.6 (Johnson and Hall, 1978). According to Johnson and Hall (1978), $x$ values higher than 0.6 can be explained by migration of iron ions into the surrounding materials, such as other silicates and glass. However, the diffusion rate of titanium ions is considerably less than that of iron ions, so that there is wide variation in composition, with $x$ values ranging from 0.3 to 0.7 (Fig.

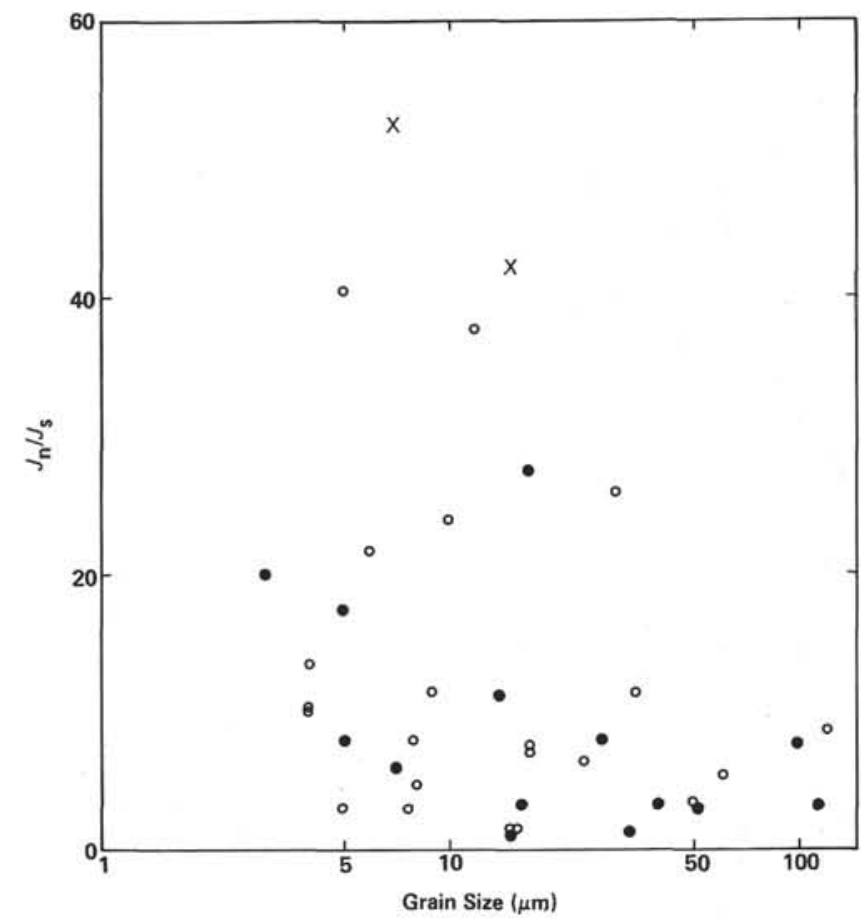

Figure 12. Relationship between intensity of NRM normalized by saturation magnetization of $\left(J_{\mathrm{n}} / J_{\mathrm{s}}\right)$ and visual grain size of titanomagnetites. Symbols are the same in Figure 1.

8). It is clear that low Ti content titanomagnetite should be generated at crystallization stage in some cases.

In type III samples, heating curves are similar to those of type II, but cooling curves show an apparent decrease in $J_{\mathrm{s}}$ and the Curie temperature. This type of thermomagnetic curve is abundant in the upper part of Hole 504B, but has been reported only rarely elsewhere (Marshall, 1978; Hamano et al., 1979). Hamano et al. (1979) carried out detailed experiments with type III samples and reported that this type of thermomagnetic behavior depends upon grain size of measured samples, which may reflect the oxygen fugacity.

The Curie temperatures of type IV curves are relatively high, ranging from 300 to $500^{\circ} \mathrm{C}$, and these samples are also found in the lower part of Hole 504B. Type IV samples are characterized by high Curie temperature and not having the characteristic dent in the thermomagnetic curve. The cooling curves of type IV samples show a decrease in $J_{s}$, and have a Curie temperature similar to type III samples. In general, the initial high Curie temperatures of submarine basalts can be explained by low-temperature oxidation, but the high $\mathrm{Cu}-$ rie temperature of the present samples cannot be explained only by oxidation. Because the thermal curves of these samples do not have a dent, which is the inversion point of oxidized titanomagnetite, we infer that the titanomagnetites in type IV samples scarcely experienced low-temperature oxidation. The $x$ values of type IV samples are around 0.6 , the normal value of oceanic basalts.

We now discuss details of type IV samples, and their decrease of Curie temperature, as well as type III thermal behavior. The samples showing type IV curves 
might be slightly oxidized at high temperatures, and we speculate that they have extremely small ilmenite exsolution lamellae, judging from their thermomagnetic properties. These lamellae cannot be detected under optical microscope or electron microprobe, because they are "immature." We believe that the Curie temperature is relatively high during the heating process, because the $x$ value of titanomagnetite may be low $(\sim 0.2)$ as a result of titanium exsolution from the original titanomagnetite. Above the Curie temperature, ilmenite lamellae may be resorbed and mixed into the host titanomagnetite, so that the curve of cooling resembles that of original titanomagnetite, but with much lower Curie temperature $\left(\sim 200^{\circ} \mathrm{C}\right)$. Hamano et al. (1979) reported that the change in Curie temperature during heating and cooling of samples of this type can be explained by reduction and mixing of the decomposed titanomagnetite and hemo-ilmenite. Momose (pers. comm.) suggests that the mixing rate of ilmenite lamellae depends on their size, with the result that it would probably be very hard for samples with well-developed lamellae having appreciable dimensions to revert to original phases.

The small range of initial compositions of titanomagnetites suggests that the interval of crystallization of titanomagnetites in submarine basalts is very limited; they are the latest phase to crystallize in the magmas. However, there is a wide range of composition of titanomagnetites in more than ten samples from Hole 504B, as implied by thermomagnetic curves. The $x$ values of these titanomagnetites range from 0.2 to 0.7 . This may imply that titanomagnetites whose $x$ values are much less than 0.6 exist in submarine basalts, and that the crystallization stage of titanomagnetite is variable in some submarine basalts. It may be that the $x$ value of titanomagnetite in all submarine basalts is not very limited, as attested by Johnson and Hall (1978).

\section{SUMMARY}

The magnetic properties that control the intensity and stability of paleomagnetic measurements of basalts from the Costa Rica Rift can be summarized as follows:

1) The intensity of NRM, the initial susceptibility, saturation magnetization, and coercive force of the basalt samples processed in this study are not significantly different from previous DSDP results.

2) The effects of hydrothermal alteration, such as low-temperature oxidation, on magnetic properties are precisely defined.

3) Thermal curves show several kinds of behavior, some of which are rarely observed in submarine basalts. The causes of differences between the normal submarine basalts and these samples is not yet clear, but may include effects of hydrothermal alteration. Another factor may be the composition of titanomagnetite, which is different from that in normal submarine basalts in some cases.

4) There is a wide range of composition in titanomagnetites in these samples, with $x$ values ranging from less than 0.3 to 0.7 . These wide ranges of chemical composition, especially the low titanium content, previously have not been found in submarine basalts. This contradicts the conclusion of Johnson and Hall (1978). Titanomagnetites with $x$ values much larger than 0.6 may be explained by the migration of iron ions (Ryall and Hall, 1980), but low $x$ values can be attributed only to the initial values of the crystallized phase.

\section{ACKNOWLEDGMENTS}

I would like to acknowledge the able assistance of the shipboard scientific and technical staff on Legs 69 and 70 . I am very grateful to O. Oshima, T. Nishitani, K. Kobayashi, and K. Momose for valuable suggestions and critical reading of the manuscript.

\section{REFERENCES}

Ade-Hall, J. M., Johnson, H. P., and Ryall, P. J. C., 1976. Rock magnetism of basalts, Leg 34. In Yeats, R. S., Hart, S. R., et al., Init. Repts. DSDP, 34: Washington (U.S. Govt. Printing Office), 459-468.

CRRUST, in press. Geothermal regimes of the Costa Rica Rift, East Pacific, investigated by drilling, DSDP-IPOD Legs 68, 69 and 70. Geol. Soc. Am. Bull.

Day, R., Fuller, M., and Shmidt, V. A., 1977. Hysteresis properties of titanomagnetites: grain-size and compositional dependence. Phys. Earth Planet. 13:260-267.

Day, R., Halgedahl, S., Steiner, M., Kobayashi, K., Furuta, T., Ishii, T., and Faller, A., 1978. Magnetic properties of basalts from DSDP Leg 49. In Luyendyk, B. P., Cann, J. R., et al., Init. Repts. DSDP, 49: Washington (U.S. Govt. Printing Office), 781-791.

Furuta, T., Kobayashi, K., and Momose, K., 1980. Magnetic properties of igneous rocks of the Philippine Sea, Deep Sea Drilling Project Leg 58. In Klein, G. deV., Kobayashi, K., et al., Init. Repts. DSDP, 58: Washington (U.S. Govt. Printing Office), 923-934.

Hamano, Y., Nishitani, T., and Kono, M., 1979. Magnetic properties of basalt samples from Deep Sea Drilling Project Holes 417D and 418A. In Donnelly, P., Francheteau, J., Bryan, W., Robinson, P., Flower, M., Salisbury, M., et al., Init. Repts. DSDP, 51, 52, 53, Pt. 2: Washington (U.S. Govt. Printing Office), 1391-1405.

Johnson, H. P., and Hall, J. M., 1978. A detailed rock magnetic and and opaque mineralogy study of the basalts from the Nazca Plate. Geophys. J. Royal Astron. Soc., 52:45-64.

Karato, S., and Becker, K., in press. Porosity and hydraulic properties of sediments from the Galapagos spreading center and their relation to hydrothermal circulation in the oceanic crust. J. Geophys. Res.

Marshall, M., 1978. The magnetic properties of some DSDP basalts from the North Pacific and inferences for Pacific Plate tectonics. J. Geophys. Res., 83:289-308.

Ozima, M., and Ozima, M., 1971. Characteristic thermomagnetic curve in submarine basalts. J. Geophys. Res., 76:2051-2056.

Ryall, P. J. C, and Hall, J. M., 1980. Iron loss in titanomagnetites during low temperature oxidation. J. Geomagnet. Geoelec., 32: 661-669. 